\title{
Monetary Policy Instability in Nigeria:A Rational Expectation Approach
}

\author{
${ }^{1}$ Onye, Kenneth Ugwu, ${ }^{2}$ Bassey, Godwin E., ${ }^{3}$ Daasi, Gibson L. K. \\ ${ }^{1}$ Department of Economics, Faculty of Social Sciences, University of Uyo, \\ ${ }^{2}$ Ph. D, Department of Economics, Faculty of Social Sciences, University of Uyo \\ ${ }^{3}$ Department of Banking and Finance, Rivers State Polytechnic, Bori
}

\begin{abstract}
This paper aims at evaluating the efficacy of monetary policy in controlling macroeconomic instability in Nigeria. The analysis performed is based on a rational expectation framework that incorporates the fiscal role of exchange rate. Using annual data spanning from 1980 to 2010, the study affirmsthat the effort of monetary policy in Nigeria aimed at influencing the finance of government fiscal deficit through the determination of the inflation-taxrate affects both the rate of inflation and the real exchange rate, thereby causing volatility in these rates. The policy import of the paper is that monetary policy should be set in such a way that the objective it seeks to achieve is well defined and articulated.
\end{abstract}

Keywords: Monetary policy; economic instability; Nigeria; rational expectation

\section{Introduction}

Generally,monetary policyseeksto achieve the basic macroeconomic goals through the attainment of economic stability. It, therefore, becomes obvious that instability in monetary policy in Nigeria cannot be appraised in isolation of macroeconomic instability. To suggest otherwise would imply a relegation or, worse still, ignorance of the essence of monetary policy. Macroeconomic instability can be regarded as a situation of economic malaise, where the economy does not seem to have settled in steady equilibrium position, thereby making it difficult to make predictions and good planning (Azam, 2001). As we see in Abiodun and Tokunbo(2006), this definition of macroeconomic instability suffers from lack of precision. The writers further note that monetary policy focuses precisely on theachievement of price stability, with respect to bothdomestic and external prices. While inflation rateis often used to track movement in domestic pricelevel, exchange rate is used as a policy tool forensuring external price stability and enhancing exportperformance (Caballero and Corbo, 1989).

This study examines the efficacy of monetarypolicy in controlling inflation rate and exchange ratevolatility or instability. As a means of achieving this, asimple monetary model with rational expectationthat emphasizes the fiscal role of the real exchangerate is used.The fiscal role of real exchange rate is particularly relevant to Nigeria since the bulk of government revenue is derived from foreign exchange earnings. The model is derived from the sunspot equilibria theory in which Woodford (1986), and Drugeon and Wignolle (1996) have demonstrated that macroeconomic instability is related to multiple (a continuum of) rational expectation equilibria.In the theoretical model, thelinks between high inflation and the joint volatility of the real exchange rate and inflation rate, as well as some aspects of government's fiscal andexchange rate policies are illustrated in a rationalexpectation equilibrium framework. In this model,inflation rate and the real exchange ratesare jointly determined by the equilibrium of the model. This study, therefore, examines how inflation as a monetary policy target, impacts onrelative prices and their instability/volatility, therebyimpairing market signals.

The rest of the study is divided into foursections. Section 2 provides an overview ofmonetary policy and macroeconomic instability in Nigeria.Section 3 presents the theoretical framework ofthe rational expectation model. Section 4 presents the empirical results and section 5 concludes the study.

\section{Overview Of Monetary Policyand Macroeconomic Instability In Nigeria (1980 - 2010)}

The role of the CBN has always been anchored on the use of monetarypolicy that is usually targeted towards theachievement of full-employment equilibrium, rapideconomic growth, price stability, and externalbalance. Over the years, the major goals ofmonetary policy have often been the two laterobjectives. Thus, exchangerate policy and inflation targeting have dominated CBN's monetary/rational expectationpolicy focus based on assumption that these areessential tools of achieving macroeconomicstability.Monetary policy in Nigeria has been carriedout through the portfolio behaviour of the CBNin terms of the control of its credit andmanagement of reserves (Abiodun and Tokunbo, 2006). Credit control measure such as the use of Open Market Operations (OMO) and selective credit are used to check movement in domestic price level, while the exchange rate policies such the fixed, managed and floating exchange rate regimes serve as measurefor 
determining the competitiveness and currentaccount performance as well as foreign reserves. Figure 2.1 and figure 2.2 show the trends in some of the Central Bank of Nigeria's (CBN's) credit control measures in history.

Figure 2.1: CBN's reserves/domestic credit. Figure 2.2:CBN's credit to Government
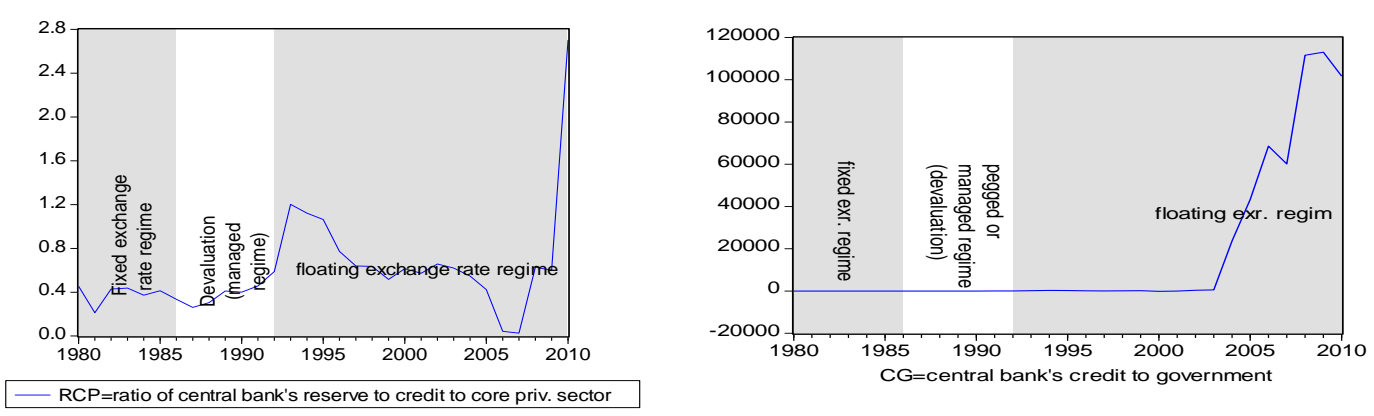

Figure 2.1 indicates that during the first half of the 1980s, CBN's reserves to domestic credit ratio witnessed continual decline.It, however, startedto increase from 1986 tillabout 1993. From late 1993, the ratio nose-dived but picked up by 2005.The trend in the ratio coincides with the three differentexchange rate regimes, namely the fixed, managed/pegged and floating exchange rate regimes. The period 1980 to 1986 (which is the era of fixed exchange regime)was marked by overvaluation of domesticcurrency, Naira vis-à-vis other trading partners' currencies (especially US dollars). The first substantialincrease in reserves was during the devaluationyears (1986-1992). However, the devaluation was characterized by managed-float exchange rate regime. InMarch 1992-when the floating exchange rate wasadopted by the merging of official exchange ratewith the parallel market rate-there was an initialshock in the system and this affected the reservespositively. But this positive shock was not sustained as evidenced by the subsequent decrease in theratio.The decrease may be attributed to great hike in CBN's creditto the Federal Government. From figure 2.2, therewas a huge increase in the allocation of credit togovernment starting from about 2000. Fromfigure 2.3 below, there was an appreciation in nominaleffective exchange rate (NEER) between thePeriod 1980 and 1993. The NEER however remained relatively stable between the periods 1993 to 1996 . Thereafter, it took a bullish trend, reaching a zenith in mid 1990s and declined thereafter. On theother hand, the general price level-proxied by the consumer price index (CPI)-is highly variegated. This has led to wide gyration and volatility (instability) in domesticprices. The trend of volatility in inflation is also buttressed in figure 2.3 as under:

Figure 2.3: Nominal Effective Exchange Rate(NEER) and Inflation (CPI), (1980-2010).

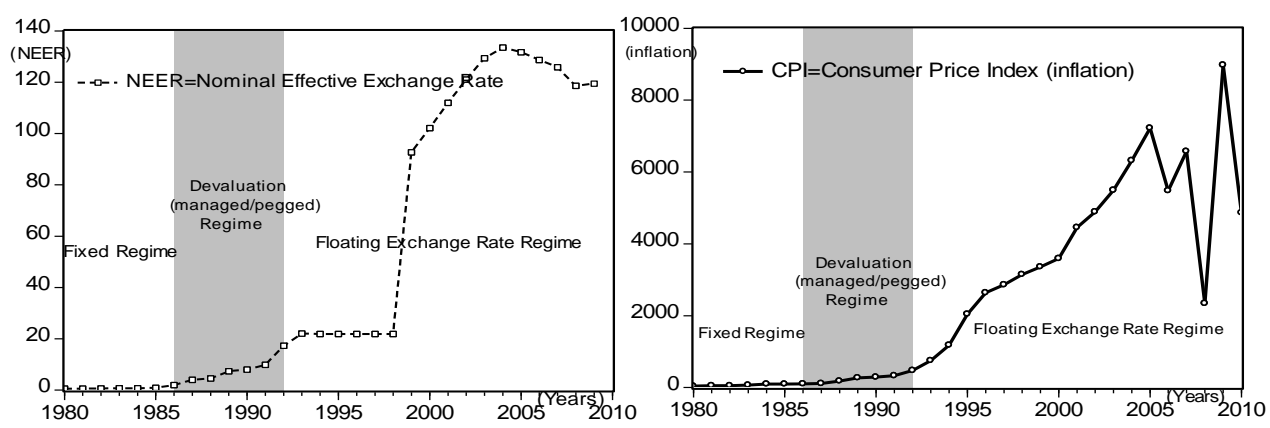

The floating exchangerate regime, starting from about 1992, brought about increase in therate of inflation with inflation reaching a peak of 72 percent in 1995 before declining to the pre-devaluation level. Similarly, there was a continuous real depreciation in the valueof Naira against the value of major tradingpartners' currencies. This situation isdepicted in figure 2.4 by the downward trend in the realeffective exchange rate (REER). 
Figure 2.4: Real Effective Exchange Rate (REER) and Inflation Rate (CPI).
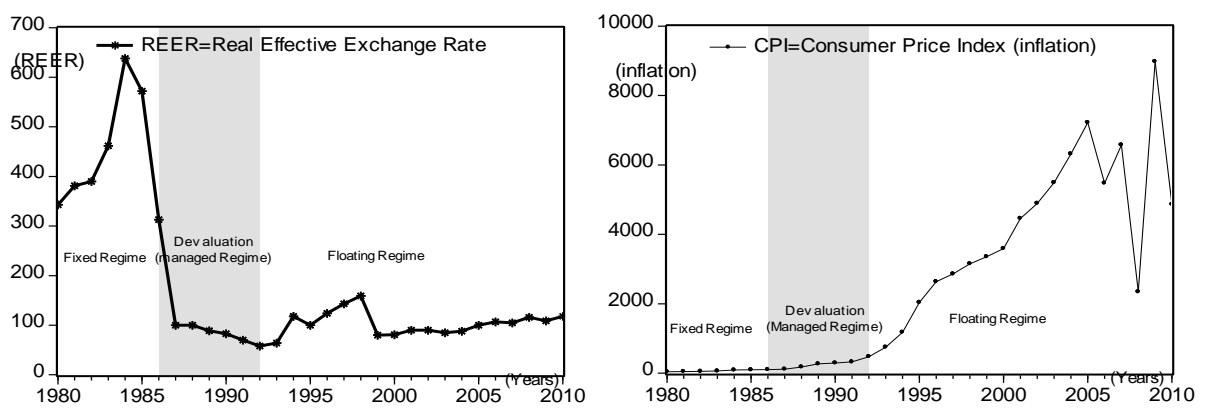

The wide swings in the trend of REER above suggest that inflation-targeting of monetary policy will only createvolatility of both inflation rate and the REER.

\section{Rate Instability}

\section{Rational Expectation Model ofinflation And Exchange}

The theoretical framework linking therelationship between instability ofREER and inflation rate adopted for this study drawsheavily from Azam (1999, 2001).In the model,international price of tradable goods in terms offoreign currency is equal to one, so that theirnominal price in domestic currency is $e$. Further,let us assume that quantity of money in theeconomy is $M$ while the price level is $\mathrm{P}$, and thatthe price level is an increasing (and linearlyhomogenous) function of e and of the price ofnon-tradable, assumed implicit in the model. If we also define $\mathrm{q}=\mathrm{e} / \mathrm{P}$ as the real exchange rate, which is an increasing (and linearly homogenous) function of $\mathrm{e}$ and of the price of tradable goods to the price of non-tradable goods. In order to effectively incorporate the fiscal role of exchange rate, government expenditures and revenues are split into two different categories, subject to how they are affected bythe exchange rate. It is assumed that governmentexpenditures are indexed on price level $\mathrm{P}$, whileits revenues (including foreign aid) are indexedon exchange rate. Therefore, let $D$ represent the excess of expenditures over revenues indexed on $P$ and $F$ the excess of revenues over expendituresindexed on $e$. Since the government budgetarypolicy is usually exogenous of stability objectiveof monetary policy, this implies that $D$ and $F$ canbe held constant. Consequently, the monetaryfinancing of the overall deficit is given by:

$\mathrm{dM} / \mathrm{dt}=\mathrm{pD}-\mathrm{eF}$

Equation 3.1 implies that the change in moneystock is used to finance fiscal deficits. If we denotethe rate of inflation by $\mp=\Delta \log p / d t$ and the rateof change in the local currency chosen bygovernment as $d=\Delta \log e / d t$. $\mathrm{d}$ is known as the rate of crawl. In Nigeria theexchange rate regime chosen by governmentdetermines the rate of crawl; therefore it isassumed that $d$ is controlled by government. Sincethe rational expectation hypothesis assumesprivate agents to have perfect knowledge aboutthe market, this then indicates that they know $\mathrm{d}$. The real rate of depreciation of the domesticcurrency is determined by the difference between the rates of change chosen by the governmentand the inflation rate, that is;

$\mathrm{dq} / \mathrm{dt}=(\mathrm{d}-\mathrm{F}) \mathrm{q}$

If we denote real money balances by $m$, thenequation 3.1 can be re-written as:

$\mathrm{dm} / \mathrm{dt}=\mathrm{D}-\mathrm{qF}-\mathrm{Fm}$

Assume that the demand for real moneybalances is determined as afunction of the expected rate of inflation $\mp^{\mathrm{e}}(\grave{a}$ la Cagan (1996)bythe function:

$\mathrm{m}=\mathrm{f}\left(\mathrm{F}^{\mathrm{e}}\right)$, where $\mathrm{f}^{\prime}<0$

Equation 3.4 holds under the assumption ofrational expectation equilibria in which case $\mp^{\mathrm{e}}=\mp$ Substituting equation 3.4 into 3.3yields :

$\mathrm{d} F / \mathrm{dt}=\left(1 / \mathrm{f}^{\prime}\right) \mathrm{dm} / \mathrm{dt}=\left[1 / \mathrm{f}^{\prime}\right][\mathrm{D}-\mathrm{dF}-\mp f(\mp)]$

$\mathrm{D}-\mathrm{qF}=\mp f(\mp)$

This implies that inflation is stabilized as $(\mathrm{d} \mp / \mathrm{dt}=0)$ for all pairs $\{\mathrm{q}, p\}$ such that: from equation 3.6, it can be seen that theinflation financed real seigniorage representedby the left hand side of the equation, is a lineardecreasing function of $q$. The negative slope ofthe function is reinforced by assuming that $D$ and $F$ to be a function of $q$, in which case it wouldbe assumed that $D^{\prime}<0$ and $F^{\prime}>0$. Theproceeds of the 
inflation tax, represented by theright hand side of equation 3.6is a non-monotonicconcave function of $p$, according to the inflation-taxLaffer-curve mechanism (see Bruno andFischer, 1990; Dornbusch and Fischer, 1993). Theinflation-tax is maximized as the aggregatemaximum of the product of expected and actualinflation rate. This gives the inflation-tax maximizing rate as:

$$
\mathrm{F}^{\max }=\operatorname{agg} \cdot \max [\mp . f(\mp)]
$$

Figures 3.1a and 3.1b analyze the combined effectof the exchange rate dynamics contained inequation 3.2 using phase diagrams. In the phasediagrams, the locus of point such that $\Delta q / \Delta t=0$ is denoted $\mathrm{Q} q$. Figure $3.1 \mathrm{~b}$ represents the casewhere the chosen rate of crawl lies below theinflation-tax maximizing inflation rate, whichconnotes a saddle point with a zero-dimensionalconvergent sub-space. Then as there is no predeterminedvariable in the system, the economyjumps instantly at point $E$ and stays there aslong as the chosen rate of crawldL $(=\mathrm{DL})$ is credible.

Figure 3.1a: dL lieabove $\mathrm{f}^{\max }$ (= INF max). Figure 3.1b: INFmax lie abovedL
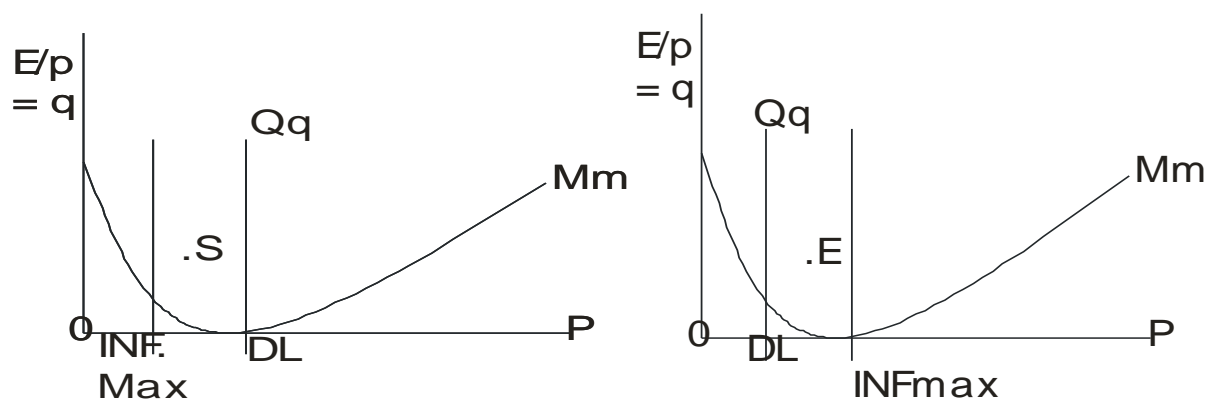

Thus, the real exchange rate and the inflation rateare uniquely determined by the chosen rate ofcrawl.From figure $3.1 \mathrm{~b}$, when the chosen rate of crawlis below the inflation-tax maximizing rate ofinflation, there will exist a unique rationalexpectation equilibrium (E) that determines jointly therate of inflation and the real exchange rate. However, in figure 3.1a, there exists a distinctresult with the chosen rate of crawl $d L$ which isgreater than the inflation-tax maximizing rate $\mathrm{F}^{\max }$ (INF max).In this case, the steady-state is stable at point (S). See Woodford (1986), and Drugeon and Wignolle (1996) for an exposition.In the practical sense, the continuum of therational expectations equilibria predicts a highvolatility for the variables in the system. Sincethe system has no anchor, the variables of the system become extremely unstable and jump fromone trajectory to the other based on the responseof private agents to information relevant to theirexpectations. Blanchard and Fischer (1989)also provide an elaborate theoretical exposition in thesunspot model that tries to capture this behaviour.

\section{Empirical Investigation}

In the application of the theoretical framework (the sunspot theory), a search procedure method (a la Hendry) which allows us to move from general to specific, is employed (Banerjee et al., 1993). This enables us to arrive at a dynamic relationship between variables of the theoretical system as applied by Azam (2001). In the empirical analysis, the data used span over 1980 and 2010. First, an investigation of the time series properties of the variables is carried out, using the Augmented Dickey-Fuller (ADF) test. The ADF-test result in table 4.1 indicates that two of the variables (CG and RCP) in the empirical model are integrated of order zero, I (0). This means that CG and RCP are stationary at their actual levels.

Table 4.1: unit root test result.

\begin{tabular}{|l|l|l|l|}
\hline ADFvariables & level & $1^{\text {st }}$ difference & Orderof integration \\
\hline CG & -41451 & $\mathrm{Na}$ & $\mathrm{I}(0)$ \\
\hline CPI & -1.2445 & -3.342 & $\mathrm{I}(1)$ \\
\hline RCP & -3.098 & na & $\mathrm{I}(0)$ \\
\hline REER & -1.3593 & -3.9147 & $\mathrm{I}(1)$ \\
\hline NEER & -2.1354 & -4.3065 & $\mathrm{I}(1)$ \\
\hline
\end{tabular}

Note: $5 \%$ critical value $=-2.8972$, na means not applicable.

On the other hand, consumer price index (CPI) and both nominal effective exchange rate (NEER) and real effective exchange rate (NEER) are integrated of order one, $I(1)$. This means that they are only stationary at their first difference. The variable RCP is used to capture the factors that determine the type of exchange rate policy measure adopted by government. 


\subsection{THE MODEL}

Following Banerjee et al (1993), the model for the empirical analysis of the volatility of real effective exchange rate (REER) is specified as follows:

REER = f[NEER, RCP, RCP(-1), CPI (-1)]

In econometric form, equation 4.1 can be restated as follows:

$\triangle \operatorname{logREER}=\beta 0+\beta 1 \Delta \operatorname{logNEER}+\beta 2 \log R C P+\beta 3 R C P(-1)+\beta 4 C P I(-1)+\mathrm{Ui}$

Where: $\mathrm{RCP}=$ ratio of CBN's Reserve to CBN's credit to private sector; REER=Real Effective Exchange Rate; NEER= Nominal Effective Exchange Rate; CPI= Consumer Price Index; (-1) means a first lag operator;

$\Delta$ mean a first difference operator. Note: The first difference is used to ensure stationarity while the natural log is used to correct possible non-linearity.

In line with the Generalized Autoregressive Conditional Heteroscedasticity (GARCH) model suggested by Ender (1995), the source of instability of REER can be investigated by testing whether inflation (CPI) is the major cause of volatility in the stochastic process of the relationship in equation 4.1. Thus, the source of volatility in REER can be tracked using equation 4.2 as follows:

$\operatorname{RES}^{2}=\mathrm{f}\left[\mathrm{CPI}, \operatorname{RES}^{2}(-1)\right]$

In econometric form, equation 4.2 can be restated as follows:

$\operatorname{RES}^{2}=\alpha 0+\alpha 1 \Delta \log C P I+\alpha 2 \operatorname{RES}^{2}(-1)+U i$ $-(4.2)$

In addition, in line with the model specified by Abiodun and Tokunbo (2006), the impact of inflation on the volatility of its own rate can be investigated using equation 4.3 as follows:

$\mathrm{CPI}=\mathrm{f}[\mathrm{NEER}, \mathrm{REER}, \mathrm{RCP}, \mathrm{CPI}(-1), \mathrm{CG}]$

By restating equation 4.3 in econometric form, we have equation $4.3 \mathrm{a}$ as follows:

$\Delta \log C P I=\varphi 0+\varphi 1 \Delta \operatorname{logNEER}+\varphi 2 \Delta \operatorname{logREER}+\varphi 3 \operatorname{logRCP}+\varphi 4 \mathrm{CPI}(-1)+\varphi 5 \log \mathrm{CG}+\mathrm{Ui}---(4.3 \mathrm{a})$

Where $\mathrm{CG}=\mathrm{Credit}$ to Government and NEER, REER, RCP and CPI are as earlier defined.

Finally, in order to isolate the actual impact of inflation on the volatility of its own rate, we perform the GARCH test similar to that of equation 4.2 by using equation 4.4 as follows:

$\operatorname{RES}^{2}=\mathrm{f}\left[\mathrm{CPI}, \operatorname{RES}^{2}(-1)\right]$

Restating equation 4.4 in econometric form, we have equation 4.4a as follows:

$\operatorname{RES}^{2}=\pi 0+\pi 1 \Delta \log C P I+\pi 2 R^{2} S^{2}(-1)+U i$-.---.-----(4.4a)

Where: $\mathrm{RES}^{2}=$ squared residual from equation 4.3a and CPI= Consumer Price Index

\subsection{EMPIRICAL RESULTS}

In the empirical analysis, the volatility of REERis examined through equation 4.1a. The result showsthat an appreciation in NEER leads to appreciation in REER and vice versa. It also shows that increase in the reserve will lead to decrease (appreciation) in REER. This is reflected by the negative sign of RCP in table 4.2 .

Table 4.2: summary of result from equation 4.1a

\begin{tabular}{|c|c|c|c|c|c|}
\hline variable & $\begin{array}{l}\text { log } \\
\text { NEER }\end{array}$ & $\begin{array}{l}\text { log } \\
\text { RCP }\end{array}$ & $\Delta \log C P I$ & $\begin{array}{l}\mathrm{RCP}(- \\
\text { 1) }\end{array}$ & CPI(-1) \\
\hline $\mathrm{Coc}$ & 0.213 & -0.212 & -0.03 & 0.214 & -0.03 \\
\hline S.E & 29.84 & 10.7 & 7.10 & 3.15 & 5.02 \\
\hline$t$-value & 5.52 & 3.72 & -4.71 & 4.21 & -4.71 \\
\hline & \multicolumn{4}{|c|}{$\mathrm{R}^{2}=0.47 ; \quad \operatorname{ARCH}(2)=14.5 ; \quad \mathrm{F}=12.98 ; \quad \mathrm{D} . \mathrm{W}=1.87$} & \\
\hline
\end{tabular}

However, one year-lagged value of RCP is positively related to REER. This means that it is actually the increase in past values of RCP that indicates the willingness of government to depreciate the naira. Further, table 4.2 shows that inflationrate is a very significant causal factor of volatility andinstabilityin REER. Increase in current periodinflation rate corresponds to a decrease (appreciation) in REER, while increase in oneperiodlagged value of inflation leads to increase (or depreciation of REER).

In equation (4.2a) we analyze the actual sourceof instability of REER by testing whether inflation is the major cause of volatility in the stochasticprocess of the relationship in equation (4.1a). To fix this, we apply the GARCH process suggested by Enders(1995). The result in table 4.3 shows that inflation isactually the major source of volatility of REER in equation (4.1a).

Table 4.3: summary of result from equation $4.2 \mathrm{a}$

\begin{tabular}{|l|c|c|}
\hline variable & $\Delta \log$ CPI & RES $^{2}(-1)$ \\
\hline Coefficient & 0.002 & 0.35 \\
\hline S.E & 0.23 & 0.08 \\
\hline t-value & 1.99 & 2.6 \\
\hline \multicolumn{2}{|c|}{$\mathrm{N}=84 ; \mathrm{R} 2=0.19 ; \mathrm{F}=8.6 ; \mathrm{LM}-\mathrm{F}=2.73$} \\
\hline
\end{tabular}


$\mathrm{RES}^{2}=$ the square of residual from equation 4.1a

Therefore,the result isindicative of the fact that the higher the level ofinflation the more will the real exchange ratedepreciate.Lastly, we investigate how inflation impacton the volatility of its own rate through changesin periodic values of the CPI. Table 4.4 showsthat depreciations (i.e increase) in both NEER and REER raisethe level of CPI.An important finding fromequation (4.3a)is the significantimpact of the past value of CPI on its variation.

Table 4.4: summary of result from equation 4.3a

\begin{tabular}{|l|c|c|c|c|c|}
\hline variable & $\Delta \operatorname{logNEER}$ & $\Delta \operatorname{logREER}$ & $\operatorname{logRCP}$ & $\log C \mathrm{G}$ & CPI(-1) \\
\hline Coefficient & 0.315 & 0.212 & -0.174 & 0.119 & 0.341 \\
\hline S.E & 11.76 & 0.77 & 0.23 & 0.93 & 0.87 \\
\hline t-value & 0.432 & 2.79 & -2.33 & 2.14 & 5.65 \\
\hline R2 $=0.53 ; \mathrm{ARCH}(2)=15.75 ; \mathrm{F}=13.08 ; \mathrm{D} . \mathrm{W}=2.13$ \\
\hline
\end{tabular}

In order to isolate the actual impact of CPI on theinstability of inflation, we perform a GARCH testsimilar to that of equation (4.2a). The result of thevolatility test shown in table 4.5 indicates that changes inCPI are positively related to the volatility of theresidual of the CPI in equation $4.3 \mathrm{a}$.

Table 4.5: summary of result from equation 4.4a

\begin{tabular}{|l|l|l|}
\hline variable & $\Delta \log C P I$ & RES $^{2}(-1)$ \\
\hline Coefficient & 0.453 & 0.07 \\
\hline S.E & 0.94 & 0.732 \\
\hline t-value & 5.33 & 1.94 \\
\hline \multicolumn{2}{|c|}{$\mathrm{N}=82 ; \mathrm{R} 2=0.35 ; \mathrm{F}=4.47 ; \mathrm{LM}-\mathrm{F}=2.43$} \\
\hline
\end{tabular}

Where RES2 $=$ the square of residual from equation $4.3 \mathrm{a}$

Overall, the results of the different analyseshave shown that inflation rate affect changes inreal exchange rate as well as its ownvolatility. Also, the effort of monetary authorityin Nigeria at using its credit and reserve astools in checking inflation andexchange rate instability has affected the volatility of the two variables over the years. Thus, monetary policy, if not well targeted could yield negative results. This is because the speculative activities of private agents frustrate monetary policy efforts. Just as improper inflation targetingcould affect real exchange rate volatility, exchange rate intervention may induce inflation (Galati, 2000). Thus, monetarypolicy should be set in such a way that the objective it seeks to achieve is well defined and in such a way that efforts at stabilizing exchange rate willnot generate inflation and vice versa.

\section{Conclusion}

This paper has investigated how monetarypolicy objective of controlling inflation rate andintervention in the financing of fiscal deficitsaffect the variability of inflation and real exchangerate. The analysis is done using a rationalexpectation framework that incorporates the fiscalrole of exchange rate. The paper has shown thatthe effort of monetary policy at influencing thefinance of government fiscal deficit through thedetermination of the inflation-tax rate affects boththe rate of inflation and the real exchange rate,thereby causing volatility in their rates. The paperrevealed that inflation affects volatility of its ownrate as well as the rate of real exchange. The policyimport of the paper is that monetary policy shouldbe set in such a way that the objective it is toachieve is well defined.

\section{References}

[1] Abiodun, O. F.,\&Tokunbo, S. O.(2006).Monetary Policy and MacroeconomicInstability in Nigeria:A Rational Expectation Approach. Journal of Social Sciences, 12, 93-100.

[2] Azam, J. -P. (1999). Institutions for Macroeconomic Stability in Africa. Journal of African Economies, 8 (2), 8-31.

[3] Azam, J. -P. 2001. Inflation and Macroeconomic Instability in Madagascar.African DevelopmentReview, 132. December: 175201.

[4] Blanchard, O. J.,\&Fischer, S. (1989). Lectures onMacroeconomics. Cambridge, MIT Press.

[5] Caballero, R. J.,\&Corbo, V.(1989). The Effect of RealExchange Rate Uncertainty on Exports: EmpiricalEvidence.World Bank Economic Review, 3, 263-278.

[6] Dornbusch, R.,\&Fischer, S. (1993). Moderate Inflation.World Bank Economic Review, 7, 1-44.

[7] Drugeon, J. -P.,\&Wignolle, B. (1996). Continuous-Time Sunspot Equilibria and Dynamics in a Model of Growth.Journal of Economic Theory, 69: 24-54.

[8] Enders, W. (1995).Applied Econometrics Time Series.New York, John Wiley and Sons.

[9] Galati, G. (2000).Forex Trading Volume, Volatility andSpreads in Emerging Market Countries.BISQuarterly Review, November. 46: $107-138$.

[10] Woodford, M. (1986).Stationary Sunspot Equilibrium in a Finance Constrained Economy.Journal ofEconomic Theory, 40, 128137. 


\section{APPENDIX 1}

DATA FOR REGRESSION ANALYSIS

\begin{tabular}{|c|c|c|c|c|c|c|c|c|c|}
\hline year & $\mathrm{CP}$ & CG & CPI & NEER & $\mathrm{R}$ & LNEER & \begin{tabular}{|l} 
LCPI \\
\end{tabular} & RCP & REER \\
\hline 1980 & 7190.9 & 3.59 & 42.3 & 0.5464 & 3268 & -0.6044 & 3.744787 & 0.454463 & 343 \\
\hline 1981 & 9654.2 & 6.61 & 51.2 & 0.61 & 2057 & -0.4943 & 3.93574 & 0.213068 & 381 \\
\hline 1982 & 11371.5 & 10.53 & 55.1 & 0.6729 & 4879.2 & -0.39616 & 4.00915 & 0.429073 & 390 \\
\hline 1983 & 12353.9 & 15.82 & 67.9 & 0.7241 & 5406 & -0.32283 & 4.218036 & 0.437595 & 462 \\
\hline 1984 & 12942 & 18.19 & 94.8 & 0.7649 & 4818.2 & -0.26801 & 4.551769 & 0.372292 & 638 \\
\hline 1984 & 13700.2 & 18.98 & 100 & 0.8938 & 5661.4 & -0.11227 & 4.60517 & 0.413235 & 572 \\
\hline 1986 & 17365 & 19.46 & 105.4 & 2.0206 & 5824.6 & 0.703394 & 4.657763 & 0.335422 & 313 \\
\hline 1987 & 25476.1 & 22.27 & 116.1 & 4.0179 & 6659.6 & 1.390759 & 4.754452 & 0.261406 & 100 \\
\hline 1988 & 29773.6 & 27.55 & 181.2 & 4.5367 & 9080 & 1.5122 & 5.199601 & 0.304968 & 100 \\
\hline 1989 & 30942.8 & 18.32 & 272.7 & 7.3916 & 12712 & 2.000344 & 5.608372 & 0.410823 & 89 \\
\hline 1090 & 36630.9 & 21.04 & 293.2 & 8.0378 & 14666 & 2.084155 & 5.680855 & 0.400372 & 83 \\
\hline 1991 & 45325.2 & 38.49 & 330.9 & 9.9095 & 20722 & 2.293494 & 5.801816 & 0.457185 & 70 \\
\hline 1992 & 61020.3 & 80.72 & 478.4 & 17.2984 & 35903 & 2.850614 & \begin{tabular}{|l|l|}
6.170447 \\
\end{tabular} & 0.588378 & 58 \\
\hline 1993 & 95285 & 189.75 & 751.9 & 22.0511 & 114542 & 3.093362 & 6.622603 & 1.202099 & 64 \\
\hline 1994 & 122273.3 & 292.16 & 1180.7 & 21.8861 & 137113 & 3.085852 & 7.073863 & 1.121365 & 118 \\
\hline 1995 & 175790 & 264.52 & 2040.4 & 21.8861 & 186994 & 3.085852 & \begin{tabular}{|l|}
7.620901 \\
\end{tabular} & 1.063735 & 100 \\
\hline 1996 & 233240 & 117.56 & 2638.1 & 21.8861 & 180280 & 3.085852 & 7.877814 & 0.772938 & 124 \\
\hline 1997 & 276490 & 59.68 & 2863.2 & 21.8861 & 176928.8 & 3.085852 & 7.959695 & 0.63991 & 143 \\
\hline 1998 & 352360 & 133.93 & 3149.2 & 21.8861 & 224202 & 3.085852 & \begin{tabular}{|l|}
8.054904 \\
\end{tabular} & 0.636287 & 159 \\
\hline 1999 & 455210 & 176.8 & 3357.6 & 92.6934 & 235250 & 4.529297 & 8.118982 & 0.516794 & 80 \\
\hline 2000 & 596000 & -110.2 & 3590.5 & 102.1052 & 366300 & 4.626004 & 8.186047 & 0.614597 & 81 \\
\hline 2001 & 854990 & -6.01 & 4458 & 111.9433 & 490207 & 4.717992 & \begin{tabular}{|l|}
8.358901 \\
\end{tabular} & 0.573348 & 90 \\
\hline 2002 & 955760 & 373.64 & 4894 & \begin{tabular}{|l}
120.9702 \\
\end{tabular} & 628718 & 4.795544 & 8.496378 & 0.65782 & 90 \\
\hline 2003 & 1035380 & 552.6 & 5493.3 & 129.3565 & 642126 & 4.862572 & 8.611284 & 0.620184 & 85 \\
\hline 2004 & 1186958 & 23759.5 & 6320.6 & 133.5004 & 650470 & 4.894104 & \begin{tabular}{|l}
8.751569 \\
\end{tabular} & 0.548014 & 88 \\
\hline 2005 & 1906838 & 43301.8 & 7220.9 & \begin{tabular}{|l|}
131.6619 \\
\end{tabular} & 808538 & 4.880237 & \begin{tabular}{|l}
8.884735 \\
\end{tabular} & 0.42402 & 100 \\
\hline 2006 & 1877414 & 68595.8 & 5474 & 128.6516 & 80573 & 4.857108 & 8.607765 & 0.042917 & 107 \\
\hline 2007 & 3889700 & 60126.4 & 6574 & 125.8331 & 100025 & 4.834956 & 8.790878 & 0.025715 & 105 \\
\hline 2008 & 7201479 & 111601 & 2345.7 & $\begin{array}{l}118.5559 \\
\end{array}$ & 4521790 & 4.775385 & 7.760339 & 0.627897 & 116 \\
\hline 2009 & 5214703 & 113012 & 8976.8 & 119.453 & 3137240 & 4.782923 & 9.102399 & 0.601614 & 109 \\
\hline 2010 & 2113107 & 101703 & 4865 & na & 5713150 & na & 8.489822 & 2.703673 & 118 \\
\hline
\end{tabular}

Source: Nigerian Bureau of Statistics (NBS), Central Bank of Nigeria (CBN) Statistical Bulletin and Annual Reports (Various Issues), World Development Indicators (WDI-statistics) from World Bank.

Where: $\mathrm{CP}=$ credit to core private sector, $\mathrm{CG}=$ credit to government, $\mathrm{CPI}=$ consumer price index, NEER=nominal effective exchange rate, $\mathrm{R}=$ reserve of $\mathrm{CBN}$, LNEER=log of NEER, LCPI=log of CPI, RCP=ratio of CBN's reserve to CBN's credit to core private sector, REER=Real effective exchange rate index $(2005=100)$ from WDI. 